10. Chan JCM 1972 The rapid determination of urinary titratable acid and ammonium and evaluation of freezing as a method of preservation. Clin Biochem 5:94-98

11. Lin SL, Chan JCM 1973 Urinary bicarbonate. A titrimetric method for determination. Clin Biochem 6:207-210

12. Broyer M 1974 Bicarbonate titration. In: Royer P. Habib R, Mathieu H, Broyer M, Walsh A (eds) Pediatric Nephrology. WB Saunders Company, Philadelphia, pp 427-428

13. Giebish $G 1976$ Effect of diuretics on renal transport of potassium. In: Martinez-maldonado $M$ (ed) Methods in Pharmacology. Plenum Press, New York, pp 121-164

14. McSherry E 1981 Renal tubular acidosis in childhood. Kidney Int 20:799-809

15. Morris RC, Sebastian A, McSherry E 1971 Renal acidosis. Kidney Int 1:327340

16. Tannen RL, Falls WE, Brackett NC 1975 Incomplete renal tubular acidosis: Some clinical and physiological features. Nephron 15:111-113

17. Rector FC 1976 Renal acidification and ammonia production. In: Brenner BM, Rector FC (eds) The Kidney. WB Saunders Company, Philadelphia, pp 3!8-343

18. Alexander EA, Levinsky $N G 1968$ An external mechanism of potassium excretion. J Clin Invest 47:740-748

19. Stokes JB 1982 Ion transport by the cortical and outer medullary collecting tubule. Kidney Int 22:473-484

20. Koeppen B. Helman SI 1982 Acidification of luminal fluid by the rabbit cortical collecting tubule perfused in vitro. Am I Physiol 242:F521-F531

21. Maline G. Klose RM, Giebisch G 1966 Micropuncture study of distal tubular potassium and sodium transport in the rat kidney. Am J Physiol 211:529547

22. Howell DS, Davis JO 1954 Relationship of sodium retention to potassium excretion by the kidney during administration of desoxycorticosterone acetate to dogs. Am J Physiol 179:359-363
23. Wright FS 1971 Increasing magnitude of electrical potential along the renal distal tubule. Am J Physiol 220:624-638

24. Batlle DC 1981 Hyperkalemic hyperchloremic metabolic acidosis associated with selective aldosterone deficiency and distal renal tubular acidosis. Semin Nephrol 1:260-274

25. Kurtzman NA, White MG, Rogers PW 1971 Aldosterone deficiency and renal bicarbonate reabsorption. J Lab Clin Med 77:931-939

26. Batlle DC, Sehy JT, Roseman MK, Arruda JAL, Kurtzman NA 1981 Clinical and pathophysiologic spectrum of acquired distal renal tubular acidosis. Kidney Int 20:389-396

27. Arruda JAL, Kurtzman NA 1980 Mechanisms and classification of deranged distal urinary acidification. Am J Physiol 239:F515-F523

28. Batle DC, Sehy JT, Roseman MK, Arruda JAL, Kurtzman NA 1981 Clinical and pathophysiologic spectrum of acquired distal renal tubular acidosis. Kidney Int 20:389--396

29. Batlle DC, Arruda JAL, Kurtzman NA 1981 Hyperkalemic distal renal tubular acidosis associated with obstructive uropathy. N Engl J Med 304:373-380

30. Batlle DC, Istarayovngyuen K, Arruda JAL, Kurtzman NA 1982 Hyperkalemic hyperchloremic metabolic acidosis in sickle cell hemoglobinopathies. Am J Med 72:188-192

31. Arruda JAL, Dytko G, Mola R, Kurtzman NA 1980 On the mechanism of lithium-induced distal renal tubular acidosis: studies in the turtle bladder. Kidney Int 17:196-204

32. Arruda JAL, Subbarayudu K, Dytko G, Mola R, Kurtzman NA 1980 Voltage dependent distal acidification defect induced by amiloride. J Lab Clin $\mathrm{Med}$ 95:407-416

33. Steinbaugh BJ, Schloeder FX, Tam SC, Goldstein MB, Halperin ML 1981 Pathogenesis of distal renal tubular acidosis. Kidney Int 19:1-7

34. Sebastian A, Hulter HN, Schambelan M 1978 Renal hyperchloremic acidosis with hyperkalemia, type 4 renal tubular acidosis. In: Proceedings of the VIlth International Congress of Nephrology, pp 351-360

\title{
Epidermal Growth Factor in Mouse Milk during Early Lactation: Lack of Dependency on Submandibular Glands
}

\author{
A. GRUETERS, J. ALM, J. LAKSHMANAN, AND D. A. FISHER
}

Department of Pediatrics, Harbor-UCLA Medical Center, Torrance, California 90509

\begin{abstract}
Using a specific and sensitive radioimmunoassay, we found epidermal growth factor (EGF) in mouse milk during early lactation in normal and sialoadenectomized mice. Levels of EGF peaked around the 6 th day postpartum and decreased thereafter up to day 12. Sephadex G-50 column chromatography of milk from normal and sialoadenectomized mice showed a single immunoreative component comigrating with purified 6045 dalton EGF from the mouse submandibular gland. The concentrations of EGF were similar in milk collected from the breast and the stomach of the offspring immediately after feeding. The molecular profiles, concentrations, and ontogeny of EGF in milk of control and sialoadenectomized mice were also similar, suggesting that the submandibular gland is
\end{abstract}

Received January 7, 1985: accepted April 2, 1985

Request for reprints should be addressed to Dr. A. Grueters, University Children's Hospital, Kavh Heubnerweg 6, D-1000 Berlin, FRG.

Supported by the National Institute of Health Grants HD-04270 (D.A.F.) and NS-17431 A (JL) At the time of this study, A.G. was a research fellow of the Department of Pediatrics, Harbor-UCLA Medical Center and J.A. was a recipient of stipends from the UCLA-Silbert International Scholars Program and Savstahomsforeningen Sweden. not the major source of EGF in mouse breast milk. (Pediatr Res 19: 853-856, 1985)

Abbreviations

EGF, epidermal growth factor

SMG, submandibular gland

RIA, radioimmunoassay

PBS, phosphate-buffered saline

EGF is present ion high concentrations in mouse $S M G$ and in lesser concentrations in many mouse and human tissues and body fluids (1-5). EGF stimulates accelerated proliferation and differentiation of skin, corneal epithelium, and lung tissue in vitro and induces a cascade of events that results in increased mitogenic activity. In vivo EGF accelerates eyelid opening and tooth eruption in newborn mice (6), and promotes functional maturation of the intestine (7) and lungs (8). Functional EGF receptors have been found in many embryonic tissues (9). 
EGF is a very energetically stable protein (10) and is biologically active when given orally (11). Human milk has been shown to possess mitogenic activity for cultured cells (12) and EGF is present in high concentrations in both human and mouse milk (13-15). However, the origin of the EGF in milk is not known. The present study was done to characterize the ontogeny and molecular profile of milk EGF during early lactation in normal and sialoadenectomized mice to determine whether the SMG contributes to milk EGF during this period.

\section{MATERIALS AND METHODS}

Animals. Adult female Swiss Webster mice (30-35 g) were purchased from Simonsen Laboratories (Gilroy, CA) and were housed individually under controlled temperature $\left(20^{\circ} \mathrm{C}\right)$ and lighting ( $12 \mathrm{~h}$ darkness $/ 12 \mathrm{~h}$ light $)$ conditions. Animals were provided with regular lab food and water ad libitum. In 30 animals the SMG and sublingual glands were removed under general anesthesia with pentobarbital. These animals had previous records of three or four successful pregnancies before the surgery. After a recovery period of $3 \mathrm{wk}$, sialoadenectomized and control females were mated with normal males; $80 \%$ of operated animals became pregnant. The day of birth was considered as day 0 , and the litter size of pups was reduced to eight per mother. No differences were observed in litter size or nursing capacity of sialoadenectomized and sham-operated animals. Moreover tooth eruption and eyelid opening occurred at similar times in pups of both groups. Mothers were separated from their pups for $4 \mathrm{~h}$ and milk samples were collected by gentle expression and suction of the breasts after intraperitoneal administration of pentobarbital and oxytocin $(160 \mathrm{mU})$. On day $0,3,6,9$, and 12 three litters from each group were killed. The stomachs of the pups were opened longitudinally and the contents removed by gentle scraping. These stomach milk and breast milk samples were frozen at $-70^{\circ} \mathrm{C}$ until analysis.

Preparation of milk homogenate supernatant. Milk samples from four mice were pooled and homogenized using a glass Teflon homogenizer in 1 to 9 volumes $(\mathrm{v} / \mathrm{v})$ of ice cold $0.05 \mathrm{M}$ (PBS, pH 7.2) containing $0.1 \%$ azide. All homogenates were spun at $100,000 \times g$ for $1 \mathrm{~h}$. The clear supernatants were used for EGF and protein determinations. In order to adjust concentrations to the EGF-RIA sensitivity range, homogenates were diluted 1:10 with RIA buffer containing $0.5 \%$ bovine serum albumin (RIA-grade), $5 \%$ normal rabbit serum, and $0.01 \%$ azide in $0.05 \mathrm{M}$ PBS. Recovery studies were performed according to Hoath et al. (16). EGF was measured using a previously described double antibody method developed in this laboratory $(16,17)$. Supernatant protein concentrations were determined by the method of Lowry et al. (18) using bovine albumin as standard. RIA results were processed using a computerized RIA program with $\log$ logit transformation of the data (19). EGF concentrations were expressed per milligram milk homogenate protein collected from the breast or stomach.

Gel exclusion chromatography. Sephadex G-50 fine resin columns $(0.9 \times 56 \mathrm{~cm})$ were equilibrated and developed with 1) 1 $\mathrm{M}$ acetic acid ( $\mathrm{pH} 2.4$ ) containing $10^{-4}$ sodium azide and 2) 0.05 M PBS ( $\mathrm{pH} 7.2$ ) containing $0.1 \%$ sodium azide at $4^{\circ} \mathrm{C}$. The columns were calibrated with blue dextran and $\mathrm{Na}{ }^{125} \mathrm{Y}(10,000$ counts/min). Unlabeled mouse SMG EGF (6045 daltons), purified by the method of Savage and Cohen (20), was applied to the column and its elution profile characterized. Aliquots of lyophilized milk samples reconstituted in $1 \mathrm{ml}$ acetic acid or $0.05 \mathrm{M}$ phosphate buffer were applied to the column in $0.5 \mathrm{ml}$ volumes and eluted by descending gravity flow $(12 \mathrm{ml} / \mathrm{h}) ; 0.5 \mathrm{ml}$ fractions were collected. Samples eluted with the acetic acid were evaporated to dryness using a speed-vac concentrator (Savant Instr. Inc., New York, NY), reconstituted in $0.3 \mathrm{ml}$ of assay buffer and assayed directly for EGF, while column fractions eluted with PBS were taken directly for EGF-RIA measurements. Student's $t$ test was used for the comparison of mean values.

\section{RESULTS}

Studies of displacement of labeled EGF in the RIA by serial dilutions of mouse milk and standard purified mouse SMG EGF (Fig. 1) generated parallel regression lines. The mean ( \pm SEM) recovery of varying amounts of standard mouse EGF added to a pool of mouse milk homogenate supernatant was $100 \pm 6 \%$ (data not shown). EGF and protein concentrations in breast milk homogenate supernatant at days 1, 3, 6, and 9 of lactation are shown in Table 1. Concentrations in milk samples collected from the stomach were similar. Protein and EGF concentrations both peaked on day 6. Breast milk homogenate supernatant EGF concentrations for control and sialoadenectomized mice are plotted in Figure 2. Values in the two groups of animals are similar at all time points.

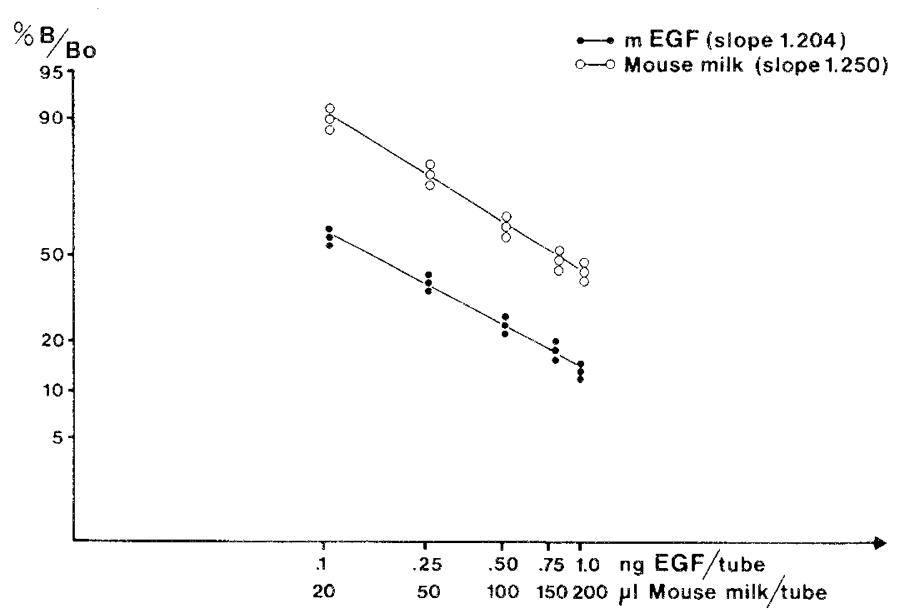

Fig. 1. Competitive binding curves of mouse SMG extract and milk in EGF-RIA.

Table 1. EGF and protein concentrations in mouse breast milk homogenate supernatants during the first 9 days of lactation (mean \pm SEM)

\begin{tabular}{cccc}
\hline Day of lactation & $n$ & Protein $(\mathrm{mg} / \mathrm{ml})$ & $\operatorname{EGF}(\mathrm{ng} / \mathrm{mg}$ protein $)$ \\
\hline 1 & 5 & $11.14 \pm 0.22$ & $2.42 \pm 0.67$ \\
3 & 5 & $13.60 \pm 0.34$ & $7.44 \pm 1.10$ \\
6 & 4 & $20.93 \pm 0.82$ & $12.65 \pm 1.29$ \\
9 & 4 & $9.60 \pm 0.01$ & $6.69 \pm 0.43$ \\
\hline
\end{tabular}

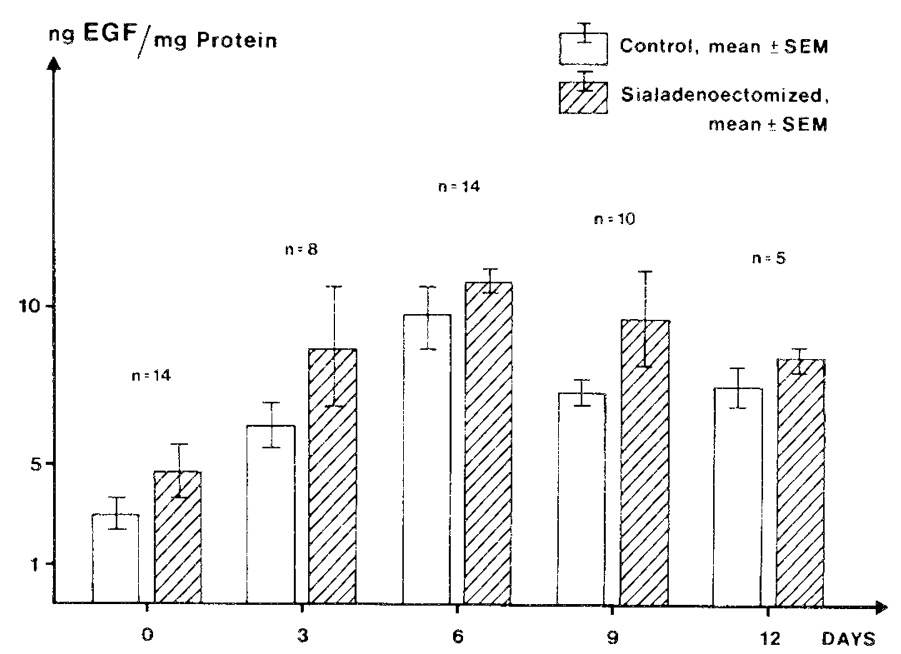

Fig. 2. EGF concentrations in mouse milk during early lactation: comparison of normal and sialoadenectomized animals. 

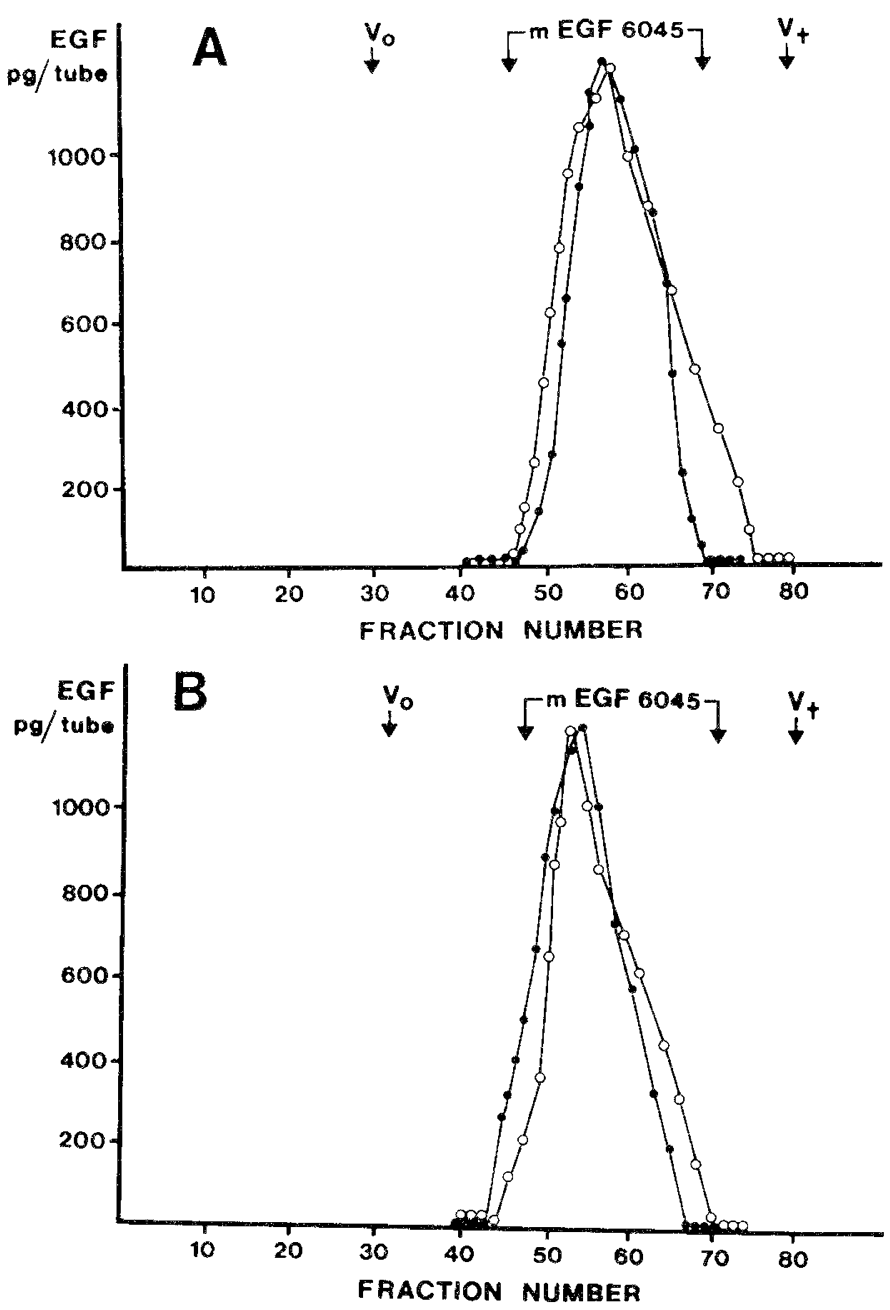

Fig. 3. A, Sephadex G-50 fine gel exclusion chromatography in $1 \mathrm{M}$ acetic acid ( $\mathrm{pH} 2.4$ ) of mouse breast milk. $B$, Sephadex G-50 fine gel exclusion chromatography in $0.05 \mathrm{M}$ phosphate buffer ( $\mathrm{pH}$ 7.2) of mouse breast milk. $O$, sham-operated breast milk; $\bullet$, sialoadenectomized breast milk.

The chromatographic profiles of milk immunoreactive EGF in control mothers at $\mathrm{pH} 2.4$ and 7.2 are shown in Figure 3. In each instance only one component was observed and this corresponded to standard mouse SMG EGF of 6045 daltons. The profiles of milk immunoreactive EGF from sialoadenectomized mice at pH 2.4 and 7.2 also were studied. Again only one immunoreactive peak was observed in each instance and again this peak comigrated with standard 6045 dalton EGF (data not shown).

\section{DISCUSSION}

In the present investigation we found high concentrations of intact EGF in mouse milk with a peak concentration at day 6 postpartum. The concentration of EGF in breast milk was independent of the presence of SMG tissue in the lactating dams. The observed concentration and the pattern of change in mouse milk EGF were found to be in good agreement with earlier observations (15). Our study was restricted to the first 12 days of lactation because this is the time of maximal growth of pups, and most of the EGF-mediated in vivo effects occur during this critical period $(6,8)$. To our knowledge the lack of influence of SMG tissue on breast milk EGF has not been reported earlier. We detected only one 6045 dalton form of EGF in milk from either normal or sialoadenectomized mothers. There was no high molecular weight EGF, as reported from urine (4). Moreover mouse milk EGF was observed to be acid stable. These results suggest that the EGF in milk of sham-operated and sialoadenectomized mice is quite similar. However, G-50 column chromatography is not adequate to exclude small differences in the EGF molecule.

The origin of EGF in mouse and human milk is not known. Recent studies in humans (1) and goats $(21,22)$ suggest passive transport of blood EGF to the mammary gland by a transcellular mechanism. Mammary cells have a dependency on EGF in vitro $(23,24)$. The existence of prepro EGF mRNA was reported recently in lactating mouse mammary gland (25). However, it is not clear whether the message is translated uitimately into EGF. Immunocytochemical studies have failed to localize EGF in mammary gland (26) despite high milk EGF content. These results suggest that EGF may not be synthesized in the mammary gland. Alternatively, it may be synthesized, but not stored, in the gland as is the case for kidney tissue (27).

If EGF in milk is derived from blood EGF, it must be concentrated in the mammary gland, presumably by high affinity receptors. Such receptors have not yet been demonstrated. The SMG represents the major pool of EGF in adult mice and SMG EGF concentrations in adult males exceed female levels by 20 - to 60 fold (1-3 versus $30-70 \mathrm{ng} / \mathrm{mg}$ wet weight, respectively) (28). In pregnant females SMG-EGF levels increase to values approximating the male and decline subsequently during lactation (28). Thus it has been suggested that EGF in mouse milk is synthesized in the SMG and transported via blood to the mammary gland. In the present study we demonstrated that the concentrations and profile of breast milk EGF are similar in control and sialoadenectomized mice. Ths result indicates that SMG is not an important source of breast milk EGF.

During the preparation of this manuscript Okamoto and Oka (29) reported that in virgin mice pregestational sialoadenectomy decreased the growth of the mammary gland and its capacity to synthesize milk leading to an increase in offspring mortality; EGF administration to sialoadenectomized pregnant mice increased survival rate of infants to almost a normal level. Although these authors observed no change in the quality of milk, removal of the submandibular gland decreased maternal serum levels of EGF during pregnancy and lactation. In our studies sialoadenectomy did not seem to impair lactation. The major difference between our studies and those of Okamoto and Oka (29) is that these investigators usually performed sialoadenectomy when the females were relatively young (50-60 days old) and experiencing a first pregnancy We used older animals (>200 days) having undergone three to four successful pregnancies before the present study. It is our experience that animals with the first two pregnancies are less suitable than more experienced dams for physiological studies involving pregnancy, nursing, and neonatal and infant mouse growth. Wide variations are observed in nesting behavior, litter size, and nursing behavior in mice during the first few pregnancies. These young female mothers often spend less time with the newborn (maternal neglect) and maternal cannibalism is greater than with the older experienced females. In addition, young mothers are very sensitive to frequent handling of pups during routine cage changes.

Other information obtained using adult sialoadenectomized female mice in our laboratory deserves comment. In a previous study (16) we reported a lack of maternal sialoadenectomy on neonatal mouse skin-EGF content. More recently we reported that sialoadenectomy in adult female mice caused no significant decrease in serum-EGF levels (30). In another study (31) we observed that sialoadenectomy of adult female mice increased urinary-EGF levels. In addtion we observed a lack of correlation between serum-EGF and SMG-EGF in mice of different age groups (32). These studies indicate that submandibular glandEGF is not the source of EGF in other tissues and physiological fluids in mice. The decreased milk production and poor nursing ability observed by Okamoto and Oka (29) in younger female 
mice may be attributable to poor adaptability to non EGFrelated physiological changes brought on by the removal of the SMG. Although the authors claim that all sialoadenectomized animals regained normal weight within $2 \mathrm{wk}$, observations in our laboratory show a decrease in weight growth velocity caused by submandibular gland excision; this could not be reversed by SMG replacement therapy (30).

The role of milk EGF is not clear. There could be local as well as systemic effects. Besides the classical in vivo effects of EGF on eyelid opening and tooth eruption, EGF has been shown to stimulate the maturation and proliferation of mucosal enterocytes (33). Oka et al. (7) have shown that EGF increases intestinal weight, intestinal lactase activity, and net calcium transport in 2-wk-old suckling rats, whereas it has no effect in 3-wk-old weanling animals. On the other hand, EGF could be absorbed; EGF is acid stable, trypsin treatment does not inhibit its biological activity (34), and radiolabeled mouse EGF given to immature rats has been shown to be at least partially absorbed unchanged and to bind to specific receptors in skin as well as intestine (35). Thus milk EGF may be important in maturation of intestine as well as other tissues in the newborn mouse.

\section{REFERENCES}

1. Hirata Y Orth D 1979 Concentrations of epidermal growth factor, nerve growth factor and submandibular gland renin in male and female mouse tissue and fluids. Endocrinology 105:1382-1388

2. Bynny RL, Orth D, Cohen S, Doyne ES 1974 Epidermal growth factor effect of androgen and adrenergic agents. Endocrinology 95:776-782

3. Starkey R, Orth D 1977 Radioimmunoassay of human epidermal growth factor (Urogastrone), J Clin Endocrinol Metab 45:1144-1153

4. Hirata Y, Orth D 1979 Epidermal growth factor (Urogastrone) in human fluids: Size heterogeneity. J Clin Endocrinol Metab 48:673-679

5. Starkey R, Cohen S. Orth DN 1975 Epidermal growth factor, identification of a new hormone in human urine. Science 189:800-802

6. Cohen S 1962 Isolation of a mouse submaxillary gland protein accelerating incisor eruption and eyelid opening in newborn animals. $J$ Biol Chem 237:1555-1562

7. Oka Y, Gishan FK, Greene HL, Orth DN 1983 Effect of mouse epidermal growth factor/urogastone on the functional maturation of rat intestine. Endocrinology 112:940-944

8. Catterton WZ, Escobedo MB, Sexson WR, Grey ME, Sundell W, Stahlmann MJ 1979 Effect of epidermal growth factor on lung maturation in fetal rabbits. Pediatr Res 13:104-108

9. Adamson ED, Oeller MJ, Warshaw JB 1981 Functional EGF receptors are present in mouse embryo tissue. Nature 291:651-659

10. Carpenter G, Cohen S 1979 Epidermal growth factor. An Rev Biochim 48: 93-216

11. Cohen S, Taylor JM 1974 Epidermal growth factor: chemical and biological characterization. Rec Prog Horm Res 30:533-550

12. Klagsbrun M 1978 Human milk stimulates DNA synthesis and cellular proliferation in cultured fibroblasts. Proc Natl Acad Sci USA 75:5057-5061

13. Carpenter G 1980 EGF is a major growth-promoting agent in human milk. Science 210:198-199

14. Moran JR, Courtney ME, Orth DN, Vaughan R, Coy S, Mount CD, Sherell BJ, Greene HL 1983 Epidermal growth factor in human milk: daily production and diurnal variation during early lactation in mothers delivering at term and at premature gestation. J Pediatr 103:402-405

15. Beardmore JM, Richards RC 1983 Concentrations of epidermal growth factor in mouse milk throughout lactation. J Endocrinol 96:287-292

16. Hoath S, Lakshmanan J, Fisher DA 1983 Effect of thyroid hormones of epidermal growth factor concentration in neonatal mouse skin. Endocrinology 112:308-314

17. Walker P, Weichsel ME, Hoath S, Poland R. Fisher DA 1981 Effect of thyroxine, testosteone and corticosterone on nerve growth factor (NGF) and epidermal growth factor (EGF) concentrations in females mouse submaxillary gland. Dissociation of NGF and EGF responses. Endocrinology 109:582-587

18. Lowry OH, Roseborough NJ, Farr AL, Randall RJ 1951 Protein measurement with folin phenol reagent. J Biol Chem 33:263-275

19. Rodbard D, Munson PJ 1980 Radioimmunoassay data processing. In: Rose NR, Friedman $\mathrm{H}$ (eds) Manual for Clinical Immunology. American Society for Microbiology, Washington DC

20. Savage CR, Cohen S 1972 Epidermal growth factor and a new derivative Rapid isolation procedures and biological and chemical characterization. J Biol Chem 247:7609-7611

21. Blakeley DM, Brown KD, Fleet IR 1982 Transfer of epidermal growth factor from blood to milk in lactating goats. Proceedings of the Physiology Society, January 1982. J Physiol 326:57P-58P

22. Brown KD, Fleet IR, Hanson M, Heap RB 1983 A method for comparing simultaneously the transport of oestrone sulphate, epidermal growth factor and amino acids across the mammary gland into milk and lymph in lactating goats. Proceedings of the Physiology Society, June 1983. J Physiol 343-15P$16 \mathrm{P}$

23. Turkington RW 1969 The role of epithelial growth factor in mammary gland development in vitro. Exp Cell Res 57:79-85

24. Tonelli QJ, Sorof $\mathrm{S} 1980$ Epidermal growth factor requirement for development of cultured mammary gland. Nature 285:250-252

25. Rall LB, Scott J, Bell GI, Crawford RJ, Penschow JD, Niall HD, Coghlan JP 1985 Mouse prepro-epidermal growth factor synthesis by the kidney and other tissues. Nature 313:228-231

26. van Noordern S, Heitz P, Kasper M, Pearse GE 1977 Mouse epidermal growth factor: light and electron microscopical localization by immunocytochemical staining. Histochemistry 52:329-333

27. Lakshmanan J, Perheentupa J, Macaso T, Fisher DA 1985 Acquisition of urine, kidney and submandibular gland epidermal growth factor responsiveness to thyroxine administration to neonatal mice. Acta Endocrinol (in press)

28. Bynny RL, Orth DN, Cohen S 1972 Radioimmunoassay of epidermal growth factor. Endocrinology 90:1262-1266

29. Okamoto S, Oka T 1984 Evidence for physiological function of epidermal growth factor: pregestational sialoadenectomy of mice decreased milk production and increases offspring mortality during lactation period. Proc Natl Acad Sci 81:6059-6063

30. Perheentupa J, Lakshmanan J, Hoath SB, Fisher DA 1984 Hormonal modulation of mouse plasma concentration of epidermal growth factor. Acta Endocrinol 107:571-576

31. Perheentupa J, Lakshmanan J, Fisher DA 1985 Epidermal growth factor in mouse urine: non blood origin, and increase by sialoadenectomy and $\mathrm{T} 4$ therapy. Acta Endocrinol 108:428-432

32. Perheentupa J, Lakshmanan J, Hoath SB, Beri U, Kim H, Macaso T, Fisher DA 1985 Epidermal growth factor in mouse plasma; method, ontogeny and sex difference. Am J Phys Endocrinol Metab 248:E391-E396

33. Malo C, Meinard D 1982 Influence of epidermal growth factor on development of suckling mouse intestinal mucosa. Gastroenterology 83:28-35

34. Savage CR, Inagami T, Cohen S 1972 The primary structure of epidermal growth factor. J Biol Chem 247:7612-7621

35. Thornburg W, Matisian L, Magun B, Koldovsky O 1984 Gastrointestinal absorption of epidermal growth factor in suckling rats. Am J Physiol 246:80 85 